\title{
Determinants of food insecurity among smallholder farmer households in Central America: recurrent versus extreme weather-driven events
}

\author{
Francisco Alpízar ${ }^{1,2}$ (D) Milagro Saborío-Rodríguez ${ }^{2,3} \cdot$ M. Ruth Martínez-Rodríguez $^{4,5} \cdot$ Bárbara Viguera $^{2} \cdot$ \\ Raffaele Vignola ${ }^{1,2} \cdot$ Tabaré Capitán $^{2} \cdot$ Celia A. Harvey ${ }^{4,6}$
}

Received: 6 March 2019 / Accepted: 16 January 2020 / Published online: 17 February 2020

(C) The Author(s) 2020

\begin{abstract}
To ensure food security among rural communities under a changing climate, policymakers need information on the prevalence and determinants of food insecurity, the role of extreme weather events in exacerbating food insecurity, and the strategies that farmers use to cope with food insecurity. Using household surveys in Guatemala and Honduras, we explore the prevalence of food insecurity among smallholder farmers on both a recurrent (seasonal) and episodic (resulting from extreme weather events) basis, analyze the factors associated with both types of food insecurity, and document farmer coping strategies. Of the 439 households surveyed, $56 \%$ experienced recurrent food insecurity, $36 \%$ experienced episodic food insecurity due to extreme weather events, and $24 \%$ experienced both types. Food insecurity among smallholder farmers was correlated with sociodemographic factors (e.g., age, education, migration) and asset ownership. The factors affecting food insecurity differed between type and prevalence of food insecurity. Our results highlight the urgent need for policies and programs to help smallholder farmers improve their overall food security and resilience to extreme weather shocks. Such policies should focus on enhancing farmer education levels, securing land tenure, empowering women, promoting generational knowledge exchange, and providing emergency food support in the lean season or following extreme weather events.
\end{abstract}

Keywords Coping strategies $\cdot$ Extreme weather events $\cdot$ Food insecurity $\cdot$ Guatemala $\cdot$ Honduras $\cdot$ Small-scale farming

Communicated by Debbie Ley

Francisco Alpízar

Francisco.Alpizar@wur.nl

Milagro Saborío-Rodríguez

milagro.saborio@ucr.ac.cr

M. Ruth Martínez-Rodríguez

ruth.martinez@un.org

Bárbara Viguera

bviguera@catie.ac.cr

Raffaele Vignola

raffaele.vignola@wur.nl

Tabaré Capitán

tcapitan@uwyo.edu

Celia A. Harvey

celiaharvey@stanfordalumni.org
1 Wageningen University and Research, $6706 \mathrm{KN}$ Wageningen, GE, Netherlands

2 Environment for Development Program, CATIE, Turrialba 30501, Costa Rica

3 School of Economics and Institute of Economics Research, University of Costa Rica, San Pedro Montes de Oca 11501, Costa Rica

4 Betty and Gordon Moore Center for Science, Conservation International, Arlington, VA 22202, USA

5 Present address: Climate Change Unit, UN Environment Regional office for Latin America and the Caribbean, Panama City, Panama

6 Present address: Monteverde Institute, Puntarenas, Monteverde, Costa Rica 


\section{Introduction}

Climate change poses a significant threat to agricultural production and food security in developing countries worldwide (Porter et al. 2014), especially to smallholder farmers who depend on agriculture for both their food security and livelihoods. Smallholder farmers are particularly vulnerable to climate change given their reliance on rain-fed agriculture, small land holdings, high poverty, low education levels, limited access to technical assistance, and lack of capital for implementing adaptation strategies, among other factors (Morton 2007; Harvey et al. 2018). Changes in temperature, rainfall patterns, and frequency of extreme weather events are already causing significant declines in the production of many staple crops such as maize (Jones and Thornton 2003), beans (Gourdji et al. 2015), and other crops (Porter and Semenov 2005), as well as key cash crops (e.g., coffee (Bunn et al. 2015)), threatening the food security and livelihoods of smallholder farmers globally.

Many national governments are developing strategies to maintain agricultural production and achieve food security under changing climatic conditions (Godfray et al. 2010; Vermeulen et al. 2012). These efforts are both in response to international agreements such as the Paris Climate Agreement and the United Nations Sustainable Development Goals (SDGs), which emphasize the importance of ensuring food security, as well as to national development agendas. Finding ways to improve the food security of smallholder farmers is critical for climate change adaptation and development goals in many developing countries (Vermeulen et al. 2012), as smallholder farmers are responsible for much of the agricultural production and are also among the most food-insecure and poorest populations and thus targets of efforts to end hunger and alleviate poverty.

Tackling food insecurity among smallholder farmers is a particular challenge in Central America, a region characterized by small-scale farming, high rates of poverty and food insecurity (Baumeister 2010), a rapidly changing climate (Magrin et al. 2014), and severe and recurrent weather hazards (Hannah et al. 2017). An estimated $14.8 \%$ of the population in Guatemala and $14.6 \%$ in Honduras suffer food insecurity between 2010 and 2012, making them the fifth and sixth most food-insecure countries in Latin America (FAO 2015). Food insecurity is likely among rural populations, which present poverty rates of $76.1 \%$ and $65.0 \%$, in Guatemala and Honduras, respectively, in contrast with urban poverty rates of $42.1 \%$ and $61.0 \%$, respectively, during 2014 (CEPAL 2013).

Climate change is expected to further exacerbate food insecurity and poverty among vulnerable smallholder farmers in the region. Central America is projected to become distinctly drier in the future, due to higher temperatures and more variable precipitation (Imbach et al. 2012, 2015). Impacts from more frequent and intense droughts, as well as extreme precipitation events, are also foreseen (IPCC 2012). These changes in climate are already causing significant declines in yields and profitability of many staple crops grown by smallholder farmers, including maize and beans (Eitzinger et al. 2012; CEPAL, CAC, SICA 2013) and coffee (Bunn et al. 2015; Hannah et al. 2017).

While there is growing recognition of the urgent need to improve the resiliency of small-scale farming systems and reduce food insecurity among rural communities in Central America (WFP 2017), these efforts are currently hindered by the lack of information on how prevalent food insecurity is and what strategies are necessary to improve farmers resiliency to climate change (Donatti et al. 2017). There is an urgent need to document levels of food insecurity among smallholder farming communities in Central America (Bacon et al. 2017), and, even more importantly, to identify which factors influence food insecurity, and what determines the choice of coping strategies used by smallholder farmers in response to food shortages. Such information could help governments more effectively target adaptation and food security policies and programs to specific smallholder farmer groups that are in greatest need of support (Ben-Davies et al. 2013).

Our study aims to help fill the knowledge gap on food insecurity among smallholder farmers by documenting its prevalence and determinants, examining the role of extreme weather events in exacerbating food insecurity, and documenting the coping strategies used by smallholder farmers in Central America. We focus our study on smallholder farmers who cultivate maize and beans for subsistence, representing the key constituents of rural communities across Central America (Baumeister 2010). We first explore how prevalent food insecurity is among smallholder farmers, and the extent to which this food insecurity is a recurrent (seasonal) event versus an episodic event resulting from extreme weather events. We use econometric methods to analyze the factors associated with recurrent food insecurity and episodic food insecurity following extreme weather events, and explore whether both types of food insecurity are associated with the same set of factors. We then zoom in to analyze those households that experience both types of food insecurity, and hence constitute a particularly vulnerable subgroup of our sample. Finally, we examine how farmers cope with episodic food insecurity, and whether the coping strategies differ between types of extreme events.

While our study focuses on determinants of food insecurity among smallholder farmers in Central America, the approach and methodology are relevant to policy makers 
and practitioners across the developing world who are interested in understanding the factors affecting food security among smallholder farmers, and the coping strategies farmers use to deal with food insecurity. The identification of strategies that can help reduce food insecurity is also widely applicable to other regions where subsistence agriculture is practiced.

\section{Methods}

To characterize patterns of both recurrent and episodic food insecurity among smallholder farmers and examine the factors affecting insecurity, we collected data on farming households in four agricultural landscapes in Central America: Acatenango and Chiquimula in Guatemala, and Choluteca and Yoro in Honduras. The landscapes were selected on the basis that they (a) were dominated by smallholder farming systems, (b) had basic grain production (beans (Phaseolus vulgaris) and/or maize (Zea mays)) as one of the key land uses, and (c) were in farming communities with low adaptive capacity to climate change according to Holland et al. (2017). Adaptive capacity is defined as the "ability of a system to adjust to climate change to moderate potential damages, to take advantage of opportunities, or to cope with the consequences" (IPCC 2007), and is measured by Holland et al. (2017) as an index that allows the comparison across landscapes and farming systems.

The four landscapes are all dominated by smallholder farming systems and are typical of the agricultural landscapes across Central America. Table 1 provides a comprehensive description of the four landscapes, and further details can be found in Harvey et al. $(2017,2018)$. The Choluteca landscape is dominated by smallholder maize and bean farmers, while the remaining landscapes include a mix of coffee and basic grain production. The farms are small, with average farm sizes ranging from 0.9 to 2.1 ha per landscape. Across all four landscapes, almost all smallholder farmers have reported significant changes in climatic conditions over the last decade, with most indicating that temperatures have risen and rainfall patterns have become more variable. In all landscapes, farmers also report having been affected by extreme weather events during the last decade, though the most harmful extreme weather event experienced differed across landscapes. A subset of farmers have made changes in their management practices in response to the perceived changes in climate, but the adaptation practices used (such as planting more trees, or intensifying use of fertilizers) vary among landscapes.

In each landscape, we randomly chose a sample of 78 to 151 smallholder households, for a total of 439 households. In order to randomly select farmers, we used remote sensing imagery to detect household roofs in each landscape and then randomly selected households from this list of potential farms for household interviews. In each household, we applied a structured survey to interview the household head about food insecurity, extreme weather events, and coping strategies, as well as sociodemographic and farm management characteristics that could be related to food insecurity. The survey design, content, and implementation process are described in detail in Alpizar et al. (2019).

In our survey, we asked farmers about the food insecurity that their households had experienced during the last decade (2004-2014). Specifically, we explored two different types of food insecurity: (1) seasonal or "recurrent" food insecurity, and (2) "episodic" food insecurity following an extreme weather event. We defined "recurrent food insecurity" as a situation where a farmer regularly experiences food insecurity each year, usually on a seasonal basis. We defined "episodic food insecurity" as the situation where farmers suffered food shortages as a result of a specific extreme weather event, such as a drought or extreme rainfall event (e.g., hurricanes, flooding, or intense rainfall). That allowed us to place households in four categories: (i) those who had not experienced any kind of food insecurity in the last decade, (ii) those who had experienced only recurrent food insecurity, (iii) those who had faced hunger only as a result of extreme weather events ("episodic food insecurity"), and (iv) those who had experienced both types of food insecurity and constitute an especially vulnerable subgroup of the population.

We used self-reported measures of household food security (similar to Bacon et al. (2017)). To assess recurrent food insecurity, we asked farmers whether they had enough food in a typical year (yes or no) and coded negative answers as recurrent food insecurity. We also asked them in which months they were food insecure. To document episodic food insecurity following an extreme weather event, we first asked households whether any extreme weather event had severely affected them in the last 10 years (2004-2014). We asked about which of the two main types of extreme weather events (drought or excessive rainfall events) affected them the most. We then asked, "did your household experience food shortages as a result of the most harmful extreme weather event that happened during the last decade?" We coded positive answers as episodic food insecurity. We also asked how many weeks they were food insecure following the extreme weather event, and what actions did the household conducted (if any) to cope with the weather-driven food shortage.

We used two modeling strategies to identify factors related to food shortages among smallholder farmers. In our first modeling approach, we estimated two equations, one for the probability of experiencing recurrent food insecurity $(\operatorname{Prob}(V=1))$ and another for the probability of experiencing episodic food insecurity $(\operatorname{Prob}(Y=1))$ :

$\operatorname{Prob}\left(V_{i}=1\right)=\mathrm{G}\left(X_{i} \beta_{v}\right)$ 


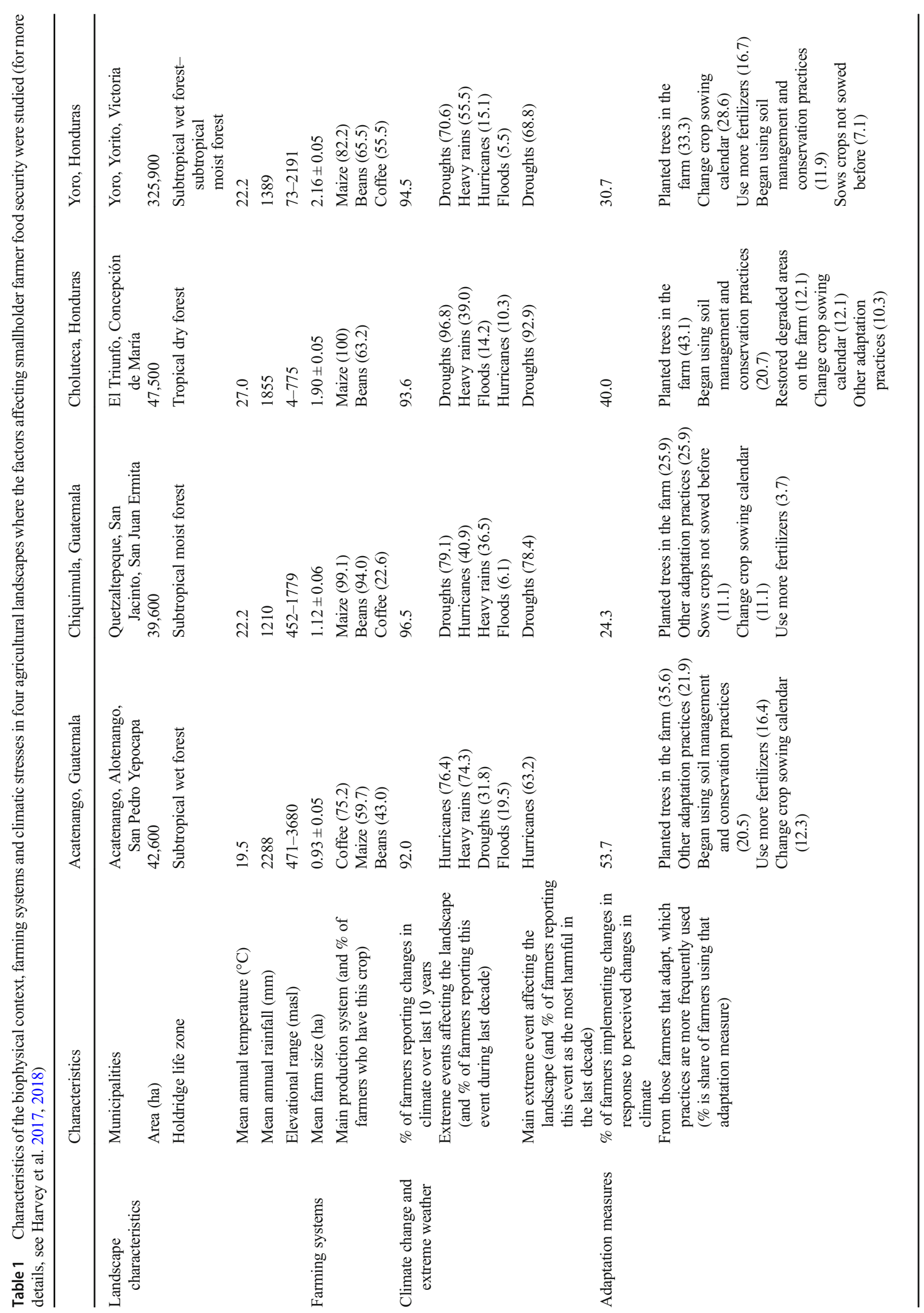


$\operatorname{Prob}\left(Y_{i}=1\right)=\mathrm{H}\left(X_{i} \beta_{y}\right)$

where $V_{i}=1$ when the household $i$ regularly experiences food shortages, and zero otherwise. This equation explored the determinants of the probability of reporting recurrent food insecurity, which is a function of the vector $X_{i}$ of explanatory variables. In the second equation, $Y_{i}=1$ when the household $i$ experiences episodic food shortages and zero if the household did not experience episodic food insecurity. This equation was used to explore how the probability of experiencing episodic food insecurity changes as a function of the vector $X_{i}$, i.e., using the same explanatory variables. We did this to test whether both types of food insecurity are explained by the same set of factors.

It is very likely that the probability of experiencing recurrent food shortages is correlated with that of experiencing episodic shortages, i.e., families that regularly face food shortages are potentially more vulnerable to spells of hunger as a result of an extreme weather event. To account for this, the two probability functions above $(\mathrm{G}($.$) and \mathrm{H}()$.$) were estimat-$ ed as a biprobit estimation, ${ }^{1}$ using the same set of explanatory variables in both equations, and assuming that the error terms are normally distributed and may be correlated (see Cameron and Trivedi (2005) for details). We also performed a Wald test of correlation of errors $(\rho)$ in the biprobit estimation (with Ho: $\rho=0$ ) to confirm the correlation between recurrent and episodic spells of food insecurity, and hence our choice of a biprobit estimation.

In these two equations, the sign and statistical significance (i.e., whether or not they are statistically different from zero) of the vectors of estimated coefficients $\left(\beta_{v} \beta_{Y}\right)$ captures the direction and relevance of changes in the explanatory variables on the probability of facing recurrent food shortages (Eq. (1)), or of facing episodic food shortages as a result of extreme events (Eq. (2)).

In our sample, there is a particular subgroup of households that reported instances of food insecurity both on a recurrent basis and also as a result of extreme weather events. In order to acquire a better understand of the factors associated with this extreme vulnerability to food insecurity, we study the determinants of belonging to that subgroup, as opposed to any other category (i.e., no food insecurity, only recurrent, or only episodic food insecurity). We estimate a probit model ${ }^{2}$ with a dependent variable $\left(Z_{i}\right)$ that takes the value of $Z_{i}=1$ if the household $i$ experienced both types of food insecurity, and 0 otherwise. The probit model estimates a vector of parameters $\beta_{z}$ for the explanatory variables $X_{i}$, as follows:

$\operatorname{Prob}\left(Z_{i}=1\right)=F\left(X_{i} \beta_{z}\right)$

\footnotetext{
${ }^{1}$ We also used a system of two linear equations with seemingly unrelated errors (SUR) as a robustness check, with no relevant change in our findings.

${ }^{2}$ As a robustness check, we also ran an ordinary least square estimation, with no relevant change in our findings..
}

The estimated coefficients $\left(\beta_{z}\right)$ capture the effect of changes in the explanatory variables on the probability that a household experiences both types of food insecurity: a positive and significant coefficient means that an increase in the respective variable increases the probability of belonging to that particularly vulnerable group. All analyses were run in STATA-13. Further details about the estimation methods can be found in Cameron and Trivedi (2005).

We selected the explanatory variables $\left(X_{i}\right)$ on the best available knowledge, our a priori expert knowledge and factors considered in similar studies of food insecurity. We used a set of 18 factors which could potentially be related to food insecurity, comprising sociodemographic characteristics of the households, ownership of assets, and access to markets, technical assistance, and social capital (Table 2). Our methods and selection of sociodemographic factors were based on similar studies of food insecurity from other developing regions (e.g., Muche et al. 2014; Douxchamps et al. 2015; Kakota et al. 2015).

Most of the sociodemographic variables are self-explanatory. With respect to education, we differentiated between general basic education and technical education associated with farming skills (equal to 1 if at least one member of the household had technical education). We included a variable for household remittances (equal to 1 if the household reported that remittances were an important, or the main source of income for the household). Ownership of assets, including livestock and vehicles (cars or motorcycles), was used as a measure of the household wealth. We also included three variables to describe land ownership: (i) the total area farmed by the household, (ii) a measure of land tenure security (equal to 1 if all the land was owned by the household, and zero if part of it was rented), and (iii) a measure of dispersion of the land farmed, that captures whether the farmer is forced to cultivate small and dispersed (non-adjacent) microplots. The microplot indicator takes a value of zero if the household produces in at least one single plot of more than 2 ha. For households working in plots of less than $2 \mathrm{ha}$, the variable takes the value of the number of small, non-adjacent plots. In this way, the variable increases as the number of small, non-adjacent plots increases. We included this variable because farmers who cultivate many microplots spend more time traveling from one plot to another and are less able to create economies of scale in inputs and labor in a single plot. On the other hand, farmers with several microplots could potentially benefit from variation in the provision of ecosystem services and resilience of the productive system, allowing them to cope better with extreme events.

Access to markets, technical assistance and social capital were measured by variables indicating whether the household sold maize and beans, sold other agricultural outputs, received the visit of an agronomist in the last 2 years, and whether the household head participated in an organization. These access 
factors have been identified as relevant determinants of food insecurity in other regions (e.g., Mango et al. 2014; Kakota et al. 2015; Velazco and Ballester 2015). We also included one factor indicating whether the extreme event experienced for the household was caused by excess of rain or drought. Finally, we included landscape fixed effects to remove any landscape-specific effects from our results.

We also analyzed the coping strategies used by households experiencing episodic food shortages by asking whether they had adjusted the amount of food consumed or their diets, or had resorted to using savings, selling livestock or working off farm to cope with food insecurity. We used a proportion test (StataCorp 2011) to compare the use of these coping strategies by different groups. Specifically, we explored if the strategies selected to cope with food insecurity were different depending on whether households were affected by an event of excessive rain versus a period of drought. Lastly, we compared the coping strategies used by households experiencing both recurrent and episodic food insecurity to the coping strategies used by those households that only experienced episodic food shortages. The proportion test allowed us to explore whether the proportion of households with a given characteristic was the same across these two groups.

\section{Results}

\section{Characteristics of smallholder farmers and farms}

Across the four landscapes, smallholder maize and bean farmers had fairly similar socioeconomic profiles (Table 3). Most of the farmers interviewed $(71.8 \%)$ were men. The average age of household heads was 47.8 years, and the mean household size was 5.4 members. The household head generally had low education levels (mean of 3.6 years of education), but $37.8 \%$ of households had at least one member with technical education. Farmers had limited access to technical support (only $12.8 \%$ had been visited by an agronomist in the past 2 years) and few assets. Among farmers, $16.2 \%$ of the households had at least one family member working off-farm, and $25.3 \%$ had a family member who had permanently migrated to obtain employment (Table 3 ).

Table 2 Potential determinants of food insecurity among smallholder farmers in four agricultural landscapes in Central America

\begin{tabular}{|c|c|c|c|c|c|c|c|c|c|c|c|}
\hline \multirow{4}{*}{ Households } & & \multicolumn{4}{|c|}{ Guatemala } & \multicolumn{4}{|c|}{ Honduras } & & \\
\hline & & \multicolumn{2}{|c|}{ Acatenango } & \multicolumn{2}{|c|}{ Chiquimula } & \multicolumn{2}{|c|}{ Choluteca } & \multicolumn{2}{|l|}{ Yoro } & \multicolumn{2}{|l|}{ Total } \\
\hline & & \multicolumn{2}{|l|}{78} & \multicolumn{2}{|l|}{101} & \multicolumn{2}{|l|}{151} & \multicolumn{2}{|l|}{109} & \multicolumn{2}{|l|}{439} \\
\hline & & Mean & $\mathrm{SD}$ & Mean & SD & Mean & $\mathrm{SD}$ & Mean & $\mathrm{SD}$ & Mean & $\mathrm{SD}$ \\
\hline \multicolumn{12}{|l|}{ Sociodemograpic factors } \\
\hline Gender ( $1=$ head is female) & Percent & 28.21 & & 26.73 & & 29.14 & & 28.44 & & 28.25 & \\
\hline Age (years) & Average & 46.92 & 14.13 & 45.31 & 13.95 & 49.81 & 16.11 & 47.94 & 14.77 & 47.79 & 15.01 \\
\hline Household size (quantity) & Average & 5.53 & 2.61 & 5.03 & 2.16 & 5.46 & 2.37 & 5.66 & 2.27 & 5.42 & 2.34 \\
\hline Head education (years) & Average & 3.40 & 3.2 & 3.53 & 3.28 & 3.61 & 2.83 & 3.78 & 3.15 & 3.60 & 3.08 \\
\hline Another HH member technical education & Percent & 30.77 & & 34.65 & & 45.03 & & 35.78 & & 37.81 & \\
\hline Household member working off farm & Percent & 32.05 & & 17.82 & & 10.60 & & 11.01 & & 16.17 & \\
\hline Permanent migrant & Percent & 10.26 & & 12.87 & & 34.43 & & 34.86 & & 25.28 & \\
\hline Remmitances are important $(1=$ important $)$ & Percent & 0.00 & & 16.67 & & 4.44 & & 12.50 & & 7.79 & \\
\hline \multicolumn{12}{|l|}{ Ownership of assets } \\
\hline Land size (ha) & Average & 1.23 & 1.32 & 1.27 & 0.96 & 2.51 & 2.47 & 2.82 & 3.70 & 2.07 & 2.54 \\
\hline Farmers working on microplots & Percent & 84.62 & & 83.17 & & 54.97 & & 57.80 & & 67.43 & \\
\hline Microplot indicator (quantity) & Average & 1.92 & 0.92 & 1.54 & 0.80 & 1.24 & 0.43 & 1.38 & 0.55 & 1.51 & 0.74 \\
\hline Owning land & Percent & 44.87 & & 36.63 & & 44.37 & & 60.55 & & 46.70 & \\
\hline Owning livestock & Percent & 12.82 & & 22.77 & & 37.75 & & 44.04 & & 31.44 & \\
\hline Owning vehicle & Percent & 20.51 & & 22.77 & & 15.89 & & 18.35 & & 18.91 & \\
\hline \multicolumn{12}{|l|}{ Access to markets, tech assist., social capital } \\
\hline Selling maize and beans & Percent & 26.92 & & 29.7 & & 35.1 & & 25.69 & & 30.07 & \\
\hline Sell or exchange other agr. outputs & Percent & 79.49 & & 38.61 & & 69.54 & & 62.39 & & 62.41 & \\
\hline Visited by agronomist & Percent & 16.67 & & 4.95 & & 13.25 & & 16.51 & & 12.76 & \\
\hline Participating in organization & Percent & 16.83 & & 23.76 & & 37.75 & & 50.46 & & 34.02 & \\
\hline
\end{tabular}

$S D$ standard deviation, $H H$ household 
In general, farmers had access to small and dispersed plots, with mean farm areas of 2.1 ha, and $43.1 \%$ of farmers having less than 2 ha. Across the four landscapes, $46.7 \%$ of farmers owned all the land they cultivate; the remainder either rented some of their land, shared land, and/or used communal land. All households produced maize and beans for home consumption, but only $30 \%$ sold maize or beans regularly. Most farmers $(62.4 \%)$ sold or exchanged other agricultural outputs (such as honey, vegetable, firewood, and fruits) and many $(31 \%)$ also owned livestock.

\section{Food insecurity levels among smallholder farmers}

Both recurrent and episodic food insecurity following extreme weather events were common among smallholder farmers (Table 3). Of the 439 households, $67.7 \%$ reported having experienced some form of food insecurity (either recurrent, episodic, or both). Across the four landscapes, $32 \%$ of households were not affected by food insecurity of any kind. Households experiencing only recurrent food insecurity made up $32 \%$ of the sample. Twelve percent of households had only experienced episodic food insecurity. The final $24 \%$ of households had experienced both types of food insecurity. On average, farmers experienced recurrent food insecurity during 3 months per year, mainly in June, July, and August (Fig. 1). The proportion of households experiencing recurrent food shortages was greater in the Honduran landscapes (proportion test, $p=0.0009$ ), but the number of months with food shortages was higher in Guatemalan landscapes ( $t$ test, $p=0.0072$ ).

Of the 439 households surveyed, $70.2 \%$ mentioned drought as the most harmful event, and $52.9 \%$ of these households experienced food shortages as a result of the drought. The remaining $29.8 \%$ reported excessive rainfall (hurricane, flooding, or torrential rainfall) as the most harmful event during the last 10 years, and of these families, $35.9 \%$ reported that the excessive rainfall event had caused them to become food insecure. The duration of food shortages after an extreme event varied among landscapes and type of event (Table 3). Similar to the incidence of regular food shortages, episodic weather-driven food shortages affected a higher proportion of households in the Honduran landscapes than in the Guatemalan landscapes (55\% versus 26\%), but impacted the Guatemalan households for longer periods than the Honduran households ( 7.7 weeks versus 4.6 weeks in average), irrespective of whether the food insecurity was triggered by drought or excessive rainfall.

\section{Factors affecting food insecurity}

The factors affecting food insecurity were different for recurrent versus episodic food insecurity, but, as expected, the probability of households experiencing recurrent food shortages was correlated with that of experiencing episodic shortages following an extreme weather event. We run a Wald test of correlation of errors in the biprobit estimations (with Ho: $\rho=0$, Wald test $=7.645$ and $p$ value $=0.006$ ), and the null hypothesis of no correlation is rejected.

Factors affecting recurrent food insecurity (columns 1 and 2, Table 4) included the age of the household head, household size, whether the household had a family member with technical education, land and vehicle ownership. The age of the household head had a negative coefficient, meaning that households with older heads were less likely to suffer recurrent spells of hunger than households with younger heads. The probability of experiencing recurrent food shortages was significantly greater for bigger households than for smaller households. If at least one member of the household had a technical education, the probability of suffering recurrent food insecurity was lower than if the households did not have members with a technical education. Households that owned their land had a lower probability of experiencing recurrent food shortages than those without this asset. Interestingly, the gender of the household head, years of education, off-farm labor, land size and vehicle ownership did not significantly explain recurrent food insecurity. Similarly, neither technical assistance nor participating in an organization affected recurrent food insecurity.

A different set of factors was related to the probability of experiencing episodes of food insecurity following an extreme weather event (columns 3 and 4, Table 4). The probability of experiencing episodic food insecurity was greater for households that had a family member who had migrated permanently and for those having many microplots, i.e., those whose land was more segregated into smaller, non-adjacent plots. In contrast, the probability of experiencing episodic food shortages was lower in households owning a vehicle and in female-headed households.

Through a probit model, we identified the factors that determine the probability of a household experiencing both types of food insecurity (Table 5). The probability of households suffering both recurrent and episodic food insecurity was lower for households with more educated heads, and for households with a member deriving income from off-farm labor. Similarly, those households owning a vehicle and participating in the market were less likely to suffer from both types of food insecurity. The microplot indicator was also a significant determinant of vulnerability: farmers with smaller, non-adjacent plots were more susceptible to both types of food insecurity than those who own at least one single plot larger than 2 ha.

\section{Coping strategies}

Smallholder farmers used various strategies to cope with episodic food shortages (Table 6). Of the 156 farmers who experienced episodic food shortages, the most common strategy to 
cope with food shortages was to decrease the quantity of food per serving or reduce the number of meals per day ("decreasing food intake" reported by $61.5 \%$ of farmers). Another strategy used by $36.9 \%$ of the farmers was to change the composition of their meals, for instance by removing meat from their diets. Other farmers (17.9\%) used their savings, sought work outside of their farm $(15.4 \%)$ or sold assets or livestock $(10.3 \%)$ to buy food. On average, farmers used a mean of 1.7 coping strategies following extreme weather events.

The strategies that farmers used to cope with extreme weather events were similar for both households affected by drought and by excessive rainfall events, except for changing diets, which was more frequent in the case of drought (Table 6, panel A). In addition, farmers facing food insecurity following drought tended to use more coping strategies than those facing food insecurity following excessive rainfall events (1.8 versus 1.5 strategies, on average $(p=0.011))$. These results are partially explained by the fact that episodes of food insecurity resulting from drought were generally longer in duration (Table 3).

Households that experienced both regular and episodic food shortages (Table 6, panel B, column 3) coped with food insecurity by reducing food intake and changing diets in a higher proportion than those that only faced episodic food shortages (Table 6, panel B, column 2). As expected, households that experienced both regular and episodic food insecurity applied more strategies (1.8 versus 1.6 on average ( $p=$ 0.046)) to cope with food shortages than those experiencing only episodic weather-driven food insecurity.

\section{Discussion}

\section{Prevalence of food insecurity among smallholder farmers}

Our results show very high rates of food insecurity among smallholder maize and bean farmers in Honduras and Guatemala, both on a recurrent basis and following extreme weather events. Across the four landscapes, the incidence of recurrent food insecurity was greatest in the months of June, July and August. This pattern of food insecurity reflects the seasonality of dry and rainy seasons and the associated agricultural calendar (Imbach et al. 2017). June is the beginning of the rainy season in Central America and is a time when many households have exhausted their food reserves from the previous harvest and are just beginning to plant their new crops. During this period, farmers are unable to work off-farm to obtain income to buy food as they need to tend their own crops, and yet their harvests are still months away (Bacon et al. 2017).

While our study is based on self-reporting of food insecurity and, like all such studies, is subjective and could potentially overreport the severity of the issue (Maxwell et al. 2008), other studies have also noted high levels of food insecurity among rural populations in Central America. For example, Morris et al. (2013) reported that $97 \%$ of smallholder coffee farmers in El Salvador depleted their maize and bean reserves during the lean months of June-September. In

Table 3 Characterization of the type and duration of food insecurity experienced by smallholder farmers in Central America

\begin{tabular}{|c|c|c|c|c|c|c|c|c|c|c|}
\hline \multirow[b]{3}{*}{ Households } & \multicolumn{4}{|c|}{ Guatemala } & \multicolumn{4}{|c|}{ Honduras } & \multicolumn{2}{|l|}{ Total } \\
\hline & \multicolumn{2}{|c|}{ Acatenango } & \multicolumn{2}{|c|}{ Chiquimula } & \multicolumn{2}{|c|}{ Choluteca } & \multicolumn{2}{|l|}{ Yoro } & & \\
\hline & \multicolumn{2}{|l|}{78} & \multicolumn{2}{|l|}{101} & \multicolumn{2}{|l|}{151} & \multicolumn{2}{|l|}{109} & \multicolumn{2}{|l|}{439} \\
\hline \multicolumn{11}{|l|}{ Type of food insecurity experienced (\%) } \\
\hline Recurrent food insecurity only & 23.08 & & 34.65 & & 32.45 & & 35.78 & & 32.12 & \\
\hline Episodic food insecurity only & 12.82 & & 9.9 & & 13.91 & & 10.09 & & 11.85 & \\
\hline Both recurrent and episodic & 15.38 & & 18.81 & & 29.8 & & 25.69 & & 23.69 & \\
\hline \multirow[t]{2}{*}{ None } & 48.72 & & 36.63 & & 23.84 & & 28.44 & & 32.35 & \\
\hline & Mean & SD & Mean & SD & Mean & SD & Mean & SD & Mean & SD \\
\hline \multicolumn{11}{|l|}{ Duration of food insecurity } \\
\hline Households affected by recurrent food insecurity & 30 & & 54 & & 94 & & 67 & & 245 & \\
\hline Number of months with food shortages & 3.83 & 1.91 & 3.02 & 1.42 & 2.8 & 1.64 & 2.81 & 1.18 & 2.98 & 1.55 \\
\hline Households affected by episodic food insecurity & 22 & & 29 & & 66 & & 39 & & 156 & \\
\hline Number of weeks of food insecurity following drought ${ }^{a}$ & & & 8.94 & 7.71 & 3.97 & 4.19 & 6.15 & 4.67 & 5.85 & 5.7 \\
\hline Number of weeks of food insecurity following excessive rainfall events & 6.45 & 9.89 & 6.83 & 8.47 & 4 & 2.83 & 5.33 & 3.77 & 6.13 & 8.2 \\
\hline $\begin{array}{l}\text { Number of weeks of food insecurity following any type of extreme } \\
\text { weather event (e.g., droughts and excessive rainfall data together) }\end{array}$ & 6.45 & 9.89 & 8.42 & 7.77 & 3.97 & 4.09 & 5.9 & 4.36 & 5.95 & 6.66 \\
\hline
\end{tabular}

${ }^{a}$ In Acatenango, drought was not mentioned as the most harmful event; consequently, there are not answers about food insecurity related to drought in this landscape 
Nicaragua, smallholder coffee farmers face food shortages for an average of 3 months per year (Bacon et al. 2017). A study in the Western Highlands of Guatemala found that almost $80 \%$ of smallholder maize farmers had suffered food insecurity at least once during the last decade (Milan and Ruano 2014) and a study of food security in the Central American Dry Corridor reported that $47 \%$ of families were foodinsecure (WFP 2015). Our study corroborates these high rates food insecurity (varying from $38.5 \%$ to $62.3 \%$ in the study landscapes, based on Table 3 ) and provides novel information on the factors associated with these rates.

In addition to facing seasonal food shortages, many farmers are also vulnerable to the threat of episodic food insecurity as a result of extreme weather events, such as droughts and extreme rainfall events. Studies in other regions (e.g., Keil et al. 2008; Harvey et al. 2014; Velazco and Ballester 2015) have similarly reported significant impacts of extreme weather events on smallholder farmer food insecurity. The high vulnerability of Central American smallholder farmers to extreme weather events is due to a combination of multiple, interacting factors, including high poverty rates, marginal lands, low agricultural production, limited access to technical support and information, poor access to capital and credit, few employment options, and low adaptive capacity (WFP 2015; Holland et al. 2017). The high incidence of episodic food insecurity following droughts and extreme rainfall events is particularly worrying for two reasons. First, the region is expected to get drier in future years (Imbach et al. 2012, 2015), and to be subjected to more frequent droughts, more intense hurricanes and other extreme weather events (IPCC 2012). Second, smallholder farmers in the region are already reporting that climate change is reducing their maize yields and increasing their food insecurity (Harvey et al. 2018).

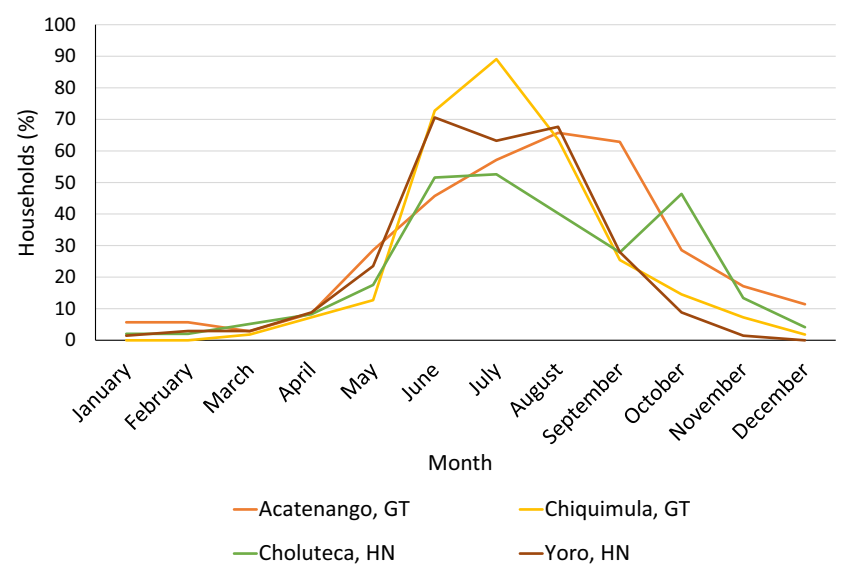

Fig. 1 Monthly distribution of recurrent food insecurity among smallholder farmers: percent of households suffering recurrent food insecurity by month in the four Central American landscapes (Acatenango $n=30$ farmers, Chiquimula $n=54$ farmers, Choluteca $n=$ 94 farmers, Yoro $n=67$ farmers)

\section{Determinants of recurrent versus episodic food insecurity among smallholder farmers}

Our study provides interesting information on the determinants of both recurrent and episodic food insecurity of small subsistence farming communities in Central America. In our study landscapes, food insecurity among smallholder maize and bean farmers was influenced by a combination of sociodemographic factors and asset ownership. Key sociodemographic factors included the age, gender and education level of the household head, family size, having a family member working off farm, having a family member with a technical education, and having a family member who had migrated to another region, while factors related to asset ownership included owning land, the number of microplots farmed, and owning a vehicle. In the following paragraphs, we describe our findings for both recurrent and episodic food insecurity, focusing on the observed differences between the two situations.

Like other studies (e.g., Gbetibouou 2009), the age of the household head played a significant role in determining household recurrent food security in our landscapes, with families headed by older farmers being less likely to experience recurrent food shortages than younger farmers. Older farmers have more experience farming and managing their food supplies than younger farmers and may therefore be better able to plan for the lean months when food supplies run low. However, interestingly, age was not a relevant determinant of episodic food shortages as a result of an extreme event, implying age does not play a significant role in coping with short-term crisis. Efforts to enhance food security among rural communities may therefore benefit by providing support to younger, less experienced farmers, and by encouraging knowledge transition from older to younger farmers. On the other hand, if a crisis ensues after an extreme weather even, age of the household head should not be considered a relevant criteria for providing short-term alleviation of food insecurity.

Households with more mouths to feed were more likely to report experiencing recurrent food shortages than smaller households. Studies of food insecurity in other developing countries (e.g., Nigeria (Idrisa et al. 2008) and Malawi (Kakota et al. 2015)) have similarly shown that larger families are more prone to suffer food insecurity, due to the need to provide food for more family members. In our landscapes, the small size of the farms (mean of $2.1 \mathrm{ha}$ ) and the limited offfarm employment opportunities (only 16\% of households had a family member working outside the farm) make it very difficult for larger families to secure enough food or money to buy food for their families throughout the year. However, family size does not appear to affect food insecurity following extreme weather events: extreme events seem to affect households equally irrespective of their size. 
Human capital is a productive asset that accumulates slowly over time. Our results show that households with at least one member having a technical education were less likely to experience recurrent food shortages than those lacking this education. Our results are similar to other studies (e.g., Maxwell et al. 2008; Davis et al. 2010; WFP 2017) that highlight the positive role of technical education in improving household food security and facilitating the implementation of on-farm adaptation measures (e.g., Morris et al. 2013), and suggest that investments in technical education should form a component of any agricultural policies or programs targeting improved food security.

Asset ownership has been mentioned in the literature as an important determinant of household's food security. In the landscapes studied, households that owned their land had a lower probability of experiencing recurrent food shortages than those households who did not own the land they cultivate. Having formal property rights allows households to adopt longer-term planning horizons and make more ambitious long-term investments in their land (such as the use of cover crops or agroforestry systems), thereby reducing their vulnerability (e.g., Harvey et al. 2014; Milan and Ruano 2014). Indeed, in our study areas, farmers who owned their land were more likely to have implemented agricultural practices that yield long-term benefits and enhance farm sustainability (Harvey et al. 2017). Another benefit of owning land is that it enables farmers to access to credits and incentives (CEPAL, FAO, IICA 2014) which can be used to improve farm productivity. All this surely contributes to reduced vulnerability to recurrent food insecurity. Still, it is important to note that owing your land is not a significant determinant of episodic food insecurity, i.e., owning your land does not exempt you from exposure to episodes of hunger as a result of an extreme weather event.

Table 4 Estimation of factors related to recurrent and episodic food insecurity in selected landscapes (biprobit estimation)

\begin{tabular}{|c|c|c|c|c|c|c|}
\hline & \multicolumn{3}{|c|}{ Recurrent food insecurity } & \multicolumn{3}{|c|}{ Episodic food insecurity } \\
\hline & Coef. & $P$ value & & Coef. & $P$ value & \\
\hline \multicolumn{7}{|l|}{ Sociodemograpic factors } \\
\hline Gender $(1=$ head is female $)$ & 0.084 & 0.573 & & -0.319 & 0.037 & $* *$ \\
\hline Age (years) & -0.009 & 0.080 & $*$ & -0.002 & 0.702 & \\
\hline Household (HH) size (quantity) & 0.068 & 0.034 & $* *$ & 0.025 & 0.403 & \\
\hline Education of HH head (years) & -0.031 & 0.186 & & -0.031 & 0.175 & \\
\hline HH member technical education ( $1=$ at least one member $)$ & -0.286 & 0.042 & $* *$ & 0.110 & 0.433 & \\
\hline HH member working off farm ( 1 = at least one member $)$ & -0.276 & 0.146 & & -0.276 & 0.151 & \\
\hline Permanent migrant $(1$ = having $)$ & 0.088 & 0.669 & & 0.381 & 0.070 & $* *$ \\
\hline Remmitances are important ( $1=$ important $)$ & 0.307 & 0.238 & & -0.130 & 0.614 & \\
\hline \multicolumn{7}{|l|}{ Ownership of assets } \\
\hline Land size (ha) & -0.017 & 0.601 & & 0.041 & 0.209 & \\
\hline Microplot indicator (quantity) & 0.056 & 0.505 & & 0.187 & 0.025 & $* *$ \\
\hline Land ownership ( 1 = all plots are owned $)$ & -0.328 & 0.017 & $* *$ & -0.022 & 0.873 & \\
\hline Owning livestock ( 1 = owning) & 0.029 & 0.848 & & 0.024 & 0.880 & \\
\hline Owning vehicle (1 = owning) & -0.269 & 0.122 & & -0.397 & 0.035 & $* *$ \\
\hline \multicolumn{7}{|l|}{ Access to markets, tech assist., social capital } \\
\hline Sell maize and beans $(1=$ selling $)$ & -0.054 & 0.703 & & 0.214 & 0.128 & \\
\hline Sell or exchange other agriculture outputs $(1=$ sell/exchange $)$ & -0.055 & 0.705 & & -0.180 & 0.214 & \\
\hline Visited by agronomist in last 2 years $(1=$ visited $)$ & 0.189 & 0.331 & & -0.098 & 0.628 & \\
\hline Participating in organization ( 1 = participating $)$ & 0.008 & 0.954 & & 0.002 & 0.987 & \\
\hline \multicolumn{7}{|l|}{ Type of event } \\
\hline Event related to excessive rainfall & & & & 0.225 & 0.213 & \\
\hline Constant & 0.087 & 0.837 & & -0.810 & 0.075 & $*$ \\
\hline Fixed effects of landscape & Yes & & & & & \\
\hline Observations & 437 & & & & & \\
\hline Wald $\chi^{2}(41)$ & 84.610 & 0.000 & $* * *$ & & & \\
\hline
\end{tabular}

HH household, Coef coefficient

$*$, **, and *** indicate $10 \%, 5 \%$, and $1 \%$ level of significance, respectively 
Focusing on the factors that significantly explain the probability of suffering hunger after an extreme event, we do find a different set of factors than for recurrent food insecurity. Female-headed households had lower probabilities of experiencing food shortages after an extreme event than male-headed households, whereas no such effect was found for recurrent food insecurity. This finding is similar to results from Bangladesh (Mallick and Rafi 2010), but contrary to those from Panama (Fuwa 2000), Kenya (Kassie et al. 2014) and Malawi (Kassie et al. 2015). It is possible that femaleheaded households were less likely to experience food insecurity when extreme weather hits because women are usually in charge of preparing meals for their families and are, therefore, more likely to plan more carefully for extreme weather events or take immediate action to cope with any food shortages arising from such events (Goh 2012; Jost et al. 2016). However, more studies are needed to better understand the gender dimensions of household food security and how agricultural development programs and adaptation strategies can more effectively support food security within female-headed households in Central America and elsewhere (Jost et al. 2016).

Migration was also clearly linked to episodic food security. In our study sites, we found that households with a permanent migrant had higher probability of experiencing episodic food shortages after a climatic shock than households without migrants, but did not differ in terms of recurrent food insecurity. In other words, permanent migration did make the household more vulnerable to climatic shocks. The fact that households with permanent migrants were more vulnerable to episodic food insecurity may be due to the reduced family labor available to work off-farm, replant crops or rebuild farm infrastructure following extreme weather events. A recent study in the Dry Corridor of Central America (World Food Programme (WFP) 2017) similarly highlighted the link between emigration and household food security, noting that in many places emigration reduced the available work force for agricultural activities, resulting in increased food insecurity and greater
Table 5 Factors associated with experiencing both types of food insecurity among smallholder farmers in selected landscapes (probit). Dependent variable is equal to 1 if household experienced both types of food insecurity, 0 otherwise

\begin{tabular}{|c|c|c|c|}
\hline & \multicolumn{3}{|c|}{ Experiencing both types of food shortages } \\
\hline & Coef. & $P$ value & \\
\hline \multicolumn{4}{|l|}{ Sociodemograpic factors } \\
\hline Gender $(1=$ head is female $)$ & -0.247 & 0.136 & \\
\hline Age (years) & -0.007 & 0.204 & \\
\hline Household (HH) size (quantity) & 0.028 & 0.371 & \\
\hline Education of HH head (years) & -0.059 & 0.017 & $* *$ \\
\hline HH member technical education $(1=$ at least one member $)$ & 0.010 & 0.944 & \\
\hline HH member working off farm $(1=$ at least one member $)$ & -0.535 & 0.021 & $* *$ \\
\hline Permanent migrant $(1=$ having $)$ & 0.302 & 0.185 & \\
\hline Remmitances are important ( 1 = important $)$ & 0.053 & 0.848 & \\
\hline \multicolumn{4}{|l|}{ Ownership of assets } \\
\hline Land size (ha) & 0.035 & 0.285 & \\
\hline Microplot indicator (quantity) & 0.181 & 0.043 & $* *$ \\
\hline Land ownership ( 1 = all plots are owned $)$ & -0.089 & 0.551 & \\
\hline Owning livestock ( 1 = owning $)$ & 0.114 & 0.518 & \\
\hline Owning vehicle ( 1 = owning) & -0.360 & 0.085 & $*$ \\
\hline \multicolumn{4}{|l|}{ Access to markets, tech assist., social capital } \\
\hline Sell maize and beans $(1=$ selling $)$ & 0.068 & 0.656 & \\
\hline Sell or exchange other agriculture outputs $(1=$ sell/exchange $)$ & -0.300 & 0.052 & $*$ \\
\hline Visited by agronomist in last 2 years $(1=$ visited $)$ & 0.321 & 0.117 & \\
\hline Participating in organization ( 1 = participating) & -0.068 & 0.656 & \\
\hline Constant & -0.598 & 0.191 & \\
\hline Fixed effects of landscape & Yes & & \\
\hline Observations & 434 & & \\
\hline$x$ & 36.040 & 0.015 & $* * *$ \\
\hline
\end{tabular}


poverty among rural families. Remittances from permanent migrants could potentially offset these negative impacts of lost family labor (Rozelle et al. 1999), but in our study landscapes, this does not appear to be the case. The increased vulnerability of households with permanent migrants to extreme weather events is alarming, given both the increasing rates of migration from Central America (World Food Programme (WFP) 2017) and the projections for extreme weather events to increase under climate change.

The quality of land holdings also played a role in determining episodic food security. In our landscapes, farmers frequently cultivate several plots that are often separated by several kilometers. This could be positive from an adaptation perspective, if having several microplots implies diversifying the exposure to external shocks. On the other hand, it could be negative if the small size of the plots inhibits the farmer from reaching an efficient scale of production and results in more costly production. In our study sites, the latter appears to be the case, as having more microplots increased the probability of experiencing episodic food shortages.

The final factor affecting episodic food insecurity is ownership of a vehicle. Of the farmers surveyed, $19 \%$ owned a vehicle (car or motorbike). Ownership of a vehicle did not affect whether or not the household suffered from recurrent food insecurity, but did significantly decrease the probability of experiencing episodic food shortages following extreme weather events. These results suggest that farmers with vehicles may have an easier time getting their products to market, buying food supplies from nearby towns, and/or pursuing offfarm labor opportunities which can provide them with the income needed to purchase food, when none is available locally. Our results show that owing a vehicle does not exempt household from suffering from recurrent food insecurity, but it surely comes in handy in case of extreme weather events.

\section{Factors affecting food insecurity among the most vulnerable farmers}

In our study landscapes, a significant proportion of farmers (15-30\% per landscape) were vulnerable to both recurrent and episodic food shortages following extreme weather events. Our analysis (Table 5) reveals the factors that affect the probability of belonging to the most vulnerable group in our sample.

Although education plays no significant role in explaining recurrent or episodic food insecurity separately, we find that

Table 6 Comparative analysis of coping strategies used by households affected by episodic food shortages (percentages and number of strategies used).

Panel A: Comparison of strategies used by households affected by drought versus an event of excessive rain.

\begin{tabular}{|c|c|c|c|c|c|}
\hline & All HH & Drought & Excess. rain & Difference & $P$ value \\
\hline Observations & 156 & 113 & 43 & & \\
\hline \multicolumn{6}{|l|}{ Strategy } \\
\hline Decrease food intake & 61.5 & 64.6 & 53.5 & 11.1 & 0.101 \\
\hline Change diet & 35.9 & 39.8 & 25.6 & 14.2 & 0.049 \\
\hline Using savings & 17.9 & 20.4 & 11.6 & 8.7 & 0.102 \\
\hline Working off-farm & 15.4 & 14.2 & 18.6 & -4.4 & 0.246 \\
\hline Selling assets or livestock & 10.3 & 11.5 & 7.0 & 4.5 & 0.203 \\
\hline Number of coping strategies used (mean) & 1.7 & 1.8 & 1.5 & 0.4 & 0.011 \\
\hline
\end{tabular}

Panel B: Comparison of strategies used by households facing only episodic versus both types of food insecurity.

\begin{tabular}{|c|c|c|c|c|c|c|}
\hline & All HH & Only episodic & Both & Difference & $\boldsymbol{P}$ value & \\
\hline Observations & 156 & 52 & 104 & & & \\
\hline \multicolumn{7}{|l|}{ Strategy } \\
\hline Decrease food intake & 61.5 & 53.8 & 65.4 & -11.5 & 0.081 & $*$ \\
\hline Change diet & 35.9 & 23.1 & 42.3 & -19.2 & 0.009 & $* * *$ \\
\hline Using savings & 17.9 & 23.1 & 15.4 & 7.7 & 0.119 & \\
\hline Working off-farm & 15.4 & 13.5 & 16.3 & -2.9 & 0.318 & \\
\hline Selling assets or livestock & 10.3 & 9.6 & 10.6 & -1.0 & 0.426 & \\
\hline Number of coping strategies used (mean) & 1.7 & 1.6 & 1.8 & -0.3 & 0.046 & $* *$ \\
\hline
\end{tabular}

Excess. rain event of excessive rainfall (hurricane, heavy rains, or flood), $H H$ households

$*, * *$, and $* * *$ indicate $10 \%, 5 \%$, and $1 \%$ level of significance, respectively

Panel A compares strategies used by households affected by drought versus excessive rainfall. Panel B compares strategies used by households that only faced episodic food insecurity, versus those experiencing both episodic and recurrent food insecurity. Only coping strategies used by at least $10 \%$ of the household are considered in the analysis 
the education level of the household head was a significant factor in explaining the overall vulnerability of a household, with more educated household heads being less likely to have suffered from both recurrent and episodic food insecurity in the last 10 years, compared to those with less educated household heads.

A similar pattern arises from the combined interpretation of Tables 4 and 5 when it comes to off-farm labor. Although off-farm labor was not a significant determinant of episodic or recurrent food insecurity individually (Table 4), it did determine whether a family is part of the most extremely vulnerable group in our sample. Families who had a member (other than the household head) working off-farm were less likely to experience both recurrent and episodic food insecurity than those without household members working off-farm, showing the importance of having a source of off-farm employment. The importance of off-farm jobs in providing income and securing the food security of subsistence farmers has also been noted elsewhere (Babatunde et al. 2010; Nyikahadzoi et al. 2012; Velazco and Ballester 2015). In a similar line, those farmers who regularly interact with the market economy, be it selling or exchanging some of their agricultural produce, were significantly less likely to be affected by both types of food insecurity. This is an important finding, as it shows the importance of the market economy even in landscapes that are strongly dominated by subsistence agriculture.

Finally, two other factors already discussed above were important in affecting the probability of belonging to the most vulnerable group in our sample: the microplot indicator and ownership of a vehicle. The significance of microplot indicator in both explaining episodic food insecurity and the probability of suffering from both episodic and recurrent food insecurity tells a compelling story of the hardship faced by farming household who have to divide their time and effort between small, and distant plots of land. Owning a vehicle is a luxury in the studied landscapes, so it comes as no surprise to find that farmers that own a vehicle are less likely to have suffered from both types of food insecurity in the last 10 years than those lacking a means of transportation.

\section{Coping strategies used by smallholder farmers}

While smallholder farmers used a variety of coping strategies to address food shortages that results from extreme weather events, many of these strategies are short-term solutions, and can potentially undermine their ability to cope with future shocks. Like smallholder farmers in other developing countries (e.g., Ramakrishna and Demeke 2002; Muche et al. 2014), many of the smallholder farmers reduced their food intake and/or adjusted their diet when food was lacking. Reducing food intake is a short-term solution that will be unsustainable if extreme events become more frequent and intense, as predicted (IPCC 2012). Reducing food intake is often accompanied by changes in diet, such as the reduction of meat intake and/or the increase in less nutritious or less preferred food (WFP 2015), both of which could have longer-term impacts on household nutrition (Lawson and Kasirye 2013). In other studies of coping strategies, households used different means to obtain income, such as selling livestock and looking for off-farm jobs (e.g., Campbell et al. 2011; Patnaik and Narayanan 2015), and resorting to aid from kindship networks and government and non-government organizations (e.g., Kinsey et al. 1998). However, in our study, savings, working off-farm and selling assets or livestock were used infrequently. In addition, very few households $(<10 \%)$ reported accessing food from government or non-government organizations among their coping strategies, likely reflecting the limited assistance available in rural areas across the region (Harvey et al. 2018).

The use of coping strategies for food insecurity following extreme weather events differed among households. Farmers who experienced both recurrent and episodic food insecurity are forced to reduce their food intake and change their diet in higher proportion, because experiencing food shortages on a recurrent basis undermines their capacity to cope with the impacts of extreme weather events. Facing drought, farmers tend to change their diet more than facing excessive rain events. That could be related to the depletion of staple foods associated with the longer duration of drought events. The general reduction in food intake and changes in diet likely results in households consuming less nutritious food and could result in lower nutritional status (FAO 2008). However, longer-term, longitudinal studies of the farmer households (including detailed nutritional studies and health measurements) would be needed to understand the long-term impacts of climate-induced food insecurity on household nutrition and health (Maxwell 1996; Barrett 2010).

\section{Conclusions and policy implications}

Our study highlights the high prevalence of food insecurity among smallholder subsistence farmers in Central America, the negative impacts of extreme weather events on smallholder farmer food security, and the limited number of coping strategies used by smallholder farmers to cope with food shortages. Our results point to the urgent need to develop policies, programs and strategies that help smallholder farmers improve their overall food insecurity (especially in the "lean" months of June-August when food insecurity is a recurring issue), as well as to increase their resilience to extreme weather shocks.

Although farmers report a series of coping strategies to address food shortages that result from extreme weather 
events, all of the strategies (with the exception of working offfarm) are short-term, finite solutions. Simply put, there is only so many savings a family can use or so much calorie intake can be decreased, before the household has run out of options. Furthermore, the main coping strategies reported by the families, for example decreasing food intake, using savings or selling assets and livestock, actually undermine their ability to cope with future shocks, in a setting in which most studies coincide in predicting an increase in the number of extreme hydrometeorological events.

Interestingly, we found that the set of factors explaining recurrent food insecurity was not the same as those explaining episodic food insecurity, with the former being more associated to long term factors, like age, size of the household, land tenure and technical education, and the latter more associated to short term availability of labor and capital to avoid the crisis. This means that policies, programs and strategies to improve food security of smallholder farmers need to be designed as long-term strategies focusing on improving farmer education, securing access to land, generating more off-farm employment opportunities, and providing greater access to technical support, and facilitating intergenerational knowledge exchange, as means to reduce recurrent food insecurity. Authorities should support households in the process of diversifying their agricultural production systems, so that farmers have a greater variety of food and income sources and are less likely to become food insecure on a recurrent basis, following an agricultural calendar that has possibly not changed in many years.

All this needs to be combined with short-term strategies that have immediate impacts after an extreme event hits the region. Short-term actions to address food insecurity include providing food, monetary, labor, or other support to farmers during or after an extreme event, possibly involving the female heads of household in the distribution of aid. There is also a need to improve preparedness and disaster relief plans, implement preventive measures such as weather monitoring and early warning systems, and ensure disaster relief efforts provide emergency food supplies and support to farmers to help them replant crops following extreme weather events.

Two key policy insights emerge when we focus on the most vulnerable subgroup in our sample, namely those households who experience recurrent food shortages, and that also have experienced episodes of hunger after an extreme event. First, access to off-farm labor and to selling agricultural produce in the market significantly decreases the probability of both types of food insecurity. The creation of markets and the provision of simple conditions for markets to work are policy instruments in the hands of donors and decision-makers. Farmers will require technical support and access to better inputs (e.g., financial, agrochemicals, improved varieties (see Harvey et al. (2018) for a full list) in order to participate in those markets, but governments and donors can also play a strong role there.
Second, having multiple, scattered small plots puts a heavy burden on the farmer's resources that can potentially be viable on a day to day basis, but that can go awfully wrong when conditions get harder. This information should be valuable for land tenure reform programs, and technical assistance programs, that should attempt to provide a scale of production that makes the farmer more capable of reaching economies of scale for different crops, and hence less vulnerable to extreme weather conditions.

As a whole, our results show that Central American households are highly vulnerable to food insecurity on a recurrent basis, and even more so after an extreme event. Although experts predict an increase in the number and intensity of extreme events, small scale farmers in the region still rely on ineffective and unsustainable preventive and/or coping strategies. Our study identifies a series of concrete policy levers available for donors and decision makers, and with recurrent food insecurity already affecting $32 \%$ of the sampled households, the need for immediate action, even before climatic predictions become a reality, is obvious.

Acknowledgments We are grateful to the 860 smallholder farmers for participating in the survey; Federico Castillo for support with field work; and Lucía Contreras for data entry and management. The household survey underwent a full review process by the Internal Review Committee of Conservation International (approved March 26th, 2014). All key personnel completed a Responsible Conduct of Research (RCR) course prior to data collection. Potential participants in the study were invited to participate, provided with information about the use of the data, and formally asked for consent to participate; they were also informed that they could withdraw from the survey at any point.

Funding information All data collection, data analysis, and write-up of the study were funded by the International Climate Initiative (IKI) of the German Federal Ministry for the Environment, Nature Conservation, Building and Nuclear Safety (BMUB). The funder had no role in the design of the study, collection, analysis, and interpretation of data, or writing of the manuscript.

Open Access This article is licensed under a Creative Commons Attribution 4.0 International License, which permits use, sharing, adaptation, distribution and reproduction in any medium or format, as long as you give appropriate credit to the original author(s) and the source, provide a link to the Creative Commons licence, and indicate if changes were made. The images or other third party material in this article are included in the article's Creative Commons licence, unless indicated otherwise in a credit line to the material. If material is not included in the article's Creative Commons licence and your intended use is not permitted by statutory regulation or exceeds the permitted use, you will need to obtain permission directly from the copyright holder. To view a copy of this licence, visit http://creativecommons.org/licenses/by/4.0/.

\section{References}

Alpizar F, Harvey CA, Saborío-Rodríguez M, Viguera B, MartínezRodríguez MR, Vignola R (2019) Household survey of climate change perception and adaptation strategies of smallholder coffee and basic grain farmers in Central America 2004-2014. [Data Collection]. Colchester, Essex: UK Data Service. https://doi.org/ 10.5255/UKDA-SN-853252 
Babatunde RO, Qaim M, Babatunde RO, Qaim M (2010) Impact of offfarm income on food security and nutrition in Nigeria. Food Policy 35:303-311. https://doi.org/10.1016/j.foodpol.2010.01.006

Bacon CM, Sundstrom WA, Stewart IT, Beezer D, Bacon CM, Sundstrom WA, Stewart IT, Beezer D (2017) Vulnerability to Cumulative Hazards: Coping with the Coffee Leaf Rust Outbreak, Drought, and Food Insecurity in Nicaragua. World Dev 93:136-152. https://doi.org/10.1016/j.worlddev.2016.12.025

Barrett CB (2010) Measuring Food Insecurity. Science 327:825-828. https://doi.org/10.1126/science. 1182768

Baumeister E (2010) Pequeños productores de granos básicos en América Central. Cuantificación, caracterización, nivel de ingresos, pobreza, y perfiles demográficos, socioeconómicos y ocupacionales. Programa Especial para la Seguridad Alimentaria (PESA) Centroamérica, Unidad Regional de Asistencia Técnica (RUTA). Honduras, 38

Ben-Davies ME, Kinlaw A, Estrada Del Campo Y, Bentley ME, SiegaRiz AM (2013) Risk factors associated with the presence and severity of food insecurity in rural Honduras. Public Health Nutr 17:5-13. https://doi.org/10.1017/S1368980013002048

Bunn C, Läderach P, Ovalle Rivera O, Kirschke D (2015) A bitter cup: climate change profile of global production of Arabica and Robusta coffee. Clim Chang 129:89-101. https://doi.org/10.1007/s10584014-1306-x

Cameron AC, Trivedi PK (2005) Microeconometrics. Methods and applications. Cambridge University Press ISBN: 0521848059

Campbell D, Barker D, McGregor D (2011) Dealing with drought: Small farmers and environmental hazards in southern St. Elizabeth, Jamaica. Appl Geogr 31:146-158. https://doi.org/10.1016/j. apgeog.2010.03.007

Comisión Económica para América Latina y el Caribe (CEPAL), Consejo Agropecuario Centroamericano (CAC), Sistema De Integración Centroamericana (SICA) (2013) Impactos potenciales del cambio climático sobre los granos básicos en Centroamérica. LC/MEX/ L.1169, México, D.F

Comisión Económica para América Latina y el Caribe (CEPAL) (2013) Panorama Social de America Latina. Naciones Unidas, Santiago de Chile, 228 p. ISBN: 978-92-1-221118-3

Comisión Económica para América Latina y el Caribe (CEPAL), Organización de las Naciones Unidas para la Alimentación (FAO), Instituto Interamericano de Cooperación para la Agricultura (IICA) (2014) Perspectivas de la agricultura y del desarrollo rural en las Américas: una mirada hacia América Latina y el Caribe. CEPAL/ FAO/IICA, Chile, 209 p. E-ISBN 978-92-5-308259-9 (PDF)

Davis B, Winters P, Carletto G, Covarrubias K, Quiñones EJ, Zezza A, Stamoulis K, Azzarri C, DiGiuseppe S (2010) A Cross-Country Comparison of Rural Income Generating Activities. World Dev 38:48-63. https://doi.org/10.1016/j.worlddev.2009.01.003

Donatti CI, Harvey CA, Martinez-Rodriguez MR, Vignola R, Rodriguez CM (2017) What information do policy makers need to develop climate adaptation plans for smallholder farmers? The case of Central America and Mexico. Clim Chang 141:107-121. https:// doi.org/10.1007/s10584-016-1787-x

Douxchamps S, van Wijk MT, Silvestri S, Moussa AS, Quiros C, Ndour NYB, Buah S, Some L, Herrero M, Kristjanson P, Ouedraogo M, Thornton PK, van Asten P, Zougmore R, Rufino MC (2015) Linking agricultural adaptation strategies, food security and vulnerability: evidence from West Africa. Reg Environ Chang. https://doi. org/10.1007/s10113-015-0838-6

Eitzinger A, Läderach P, Sonder K, Schmidt A, Sain G, Beebe S, Rodríguez B, Fisher M, Hicks P, Navarrete-Frías C, Nowak A (2012) Tortillas on the Roaster : Central America's Maize - Bean Systems and the Changing Climate. CIAT Policy Brief. Centro Internacional de Agricultura Tropical (CIAT), Cali, Colombia. 6
Food and Agriculture Organization of the United Nations (FAO) (2008) Climate change and food security: A framework document. Rome, IT. $p 93$

Food and Agriculture Organization of the United Nations (FAO) (2015) Regional overview of food insecurity: Latin America and the Caribbean. 74. https://doi.org/10.1080/04597238108460570

Fuwa N (2000) The Poverty and Heterogeneity Among Female-Headed Households Revisited: The Case of Panama. World Dev 28:15151542. https://doi.org/10.1016/S0305-750X(00)00036-X

Gbetibouo GA (2009) Understanding farmers perceptions and adaptations to climate change and variability: the case of the Limpopo basin, South Africa. IFPRI Discussion Paper 849. Washington, D.C. (USA)

Godfray HCJ, Beddington JR, Crute IR, Haddad L, Lawrence D, Muir JF, Pretty J, Robinson S, Thomas SM, Toulmin C (2010) Food Security : The Challenge of Feeding 9 Billion people. Science 327:812-818. https://doi.org/10.1126/science.1185383

Goh AHX (2012) A literature review of the gender-differentiated impacts of climate change on women's and men's assets and well-being in developing countries. CAPRi Working Paper No. 106. Washington, D.C.: International Food Policy Research Institute. 44 p. https://doi. org/10.2499/CAPRiWP106

Gourdji S, Läderach P, Valle AM, Martinez CZ, Lobell DB (2015) Historical climate trends, deforestation, and maize and bean yields in Nicaragua. Agric For Meteorol 200:270-281. https://doi.org/10. 1016/j.agrformet.2014.10.002

Hannah L, Donatti CI, Harvey CA, Alfaro E, Rodriguez DA, Bouroncle C, Castellanos E, Diaz F, Fung E, Hidalgo HG, Imbach P, Läderach P, Landrum JP, Solano AL (2017) Regional modeling of climate change impacts on smallholder agriculture and ecosystems in Central America. Clim Chang 141:29-45. https://doi.org/10.1007/ s10584-016-1867-y

Harvey CA, Chacón M, Donatti CI, Garen E, Hannah L, Andrade A, Bede L, Brown D, Calle A, Chará J, Clement C, Gray E, Hoang $\mathrm{MH}$, Minang P, Rodríguez AM, Seeberg-Elverfeldt C, Semroc B, Shames S, Smukler S, Somarriba E, Torquebiau E, van Etten J, Wollenberg E (2014) Climate-Smart Landscapes: Opportunities and Challenges for Integrating Adaptation and Mitigation in Tropical Agriculture. Conserv Lett 7:77-90. https://doi.org/10. 1111/conl.12066

Harvey CA, Martínez-Rodríguez MR, Cárdenas JM, Avelino J, Rapidel B, Vignola R, Donatti CI, Vilchez-Mendoza S (2017) The use of Ecosystem-based Adaptation practices by smallholder farmers in Central America. Agric Ecosyst Environ 246:279-290. https://doi. org/10.1016/j.agee.2017.04.018

Harvey CA, Saborío-Rodríguez M, Martinez-Rodriguez MR, Viguera B, Chain-Guadarrama A, Vignola R, Alpizar F (2018) Climate change impacts and adaptation among smallholder farmers in Central America. Agric Food Secur 7(57):1-20. https://doi.org/10.1186/ s40066-018-0209-x Agriculture

Holland MB, Shamer SZ, Imbach P, Zamora JC, Medellin Moreno C, Hidalgo EJL, Donatti CI, Martínez-Rodríguez MR, Harvey CA (2017) Mapping adaptive capacity and smallholder agriculture: applying expert knowledge at the landscape scale. Clim Chang 141: 139-153. https://doi.org/10.1007/s10584-016-1810-2

Idrisa YL, Gwary MM, Shehu H (2008) Analysis of food security status among farming households in Jere Local Government of Borno State, Nigeria. Journal of Tropical Agriculture, Food, Environment and Extension 7(3):199-205. https://doi.org/10.4314/as.v7i3.45552

Imbach P, Molina L, Locatelli B, Roupsard O, Mahé G, Neilson R, Corrales L, Scholze M, Ciais P (2012) Modeling potential equilibrium states of vegetation and terrestrial water cycle of Mesoamerica under climate change scenarios. J Hydrometeorol 13:665-680. https://doi.org/10.1175/JHM-D-11-023.1

Imbach P, Locatelli B, Zamora JC, Fung E, Calderer L, Molina L, Ciais P (2015) Impacts of climate change on ecosystem hydrological services 
of Central America: water availability. In: Chiabai A (ed) Climate change impacts on tropical forests in Central America: an ecosystem service perspective, pp 65-90 ISBN: 978-0-415-72080-9

Imbach P, Beardsley M, Bouroncle C, Medellin C, Läderach P, Hidalgo H, Alfaro E, Van Etten J, Allan R, Hemming D, Stone R, Hannah L, Donatti CI (2017) Climate change, ecosystems and smallholder agriculture in Central America: an introduction to the special issue. Clim Chang 141:1-12. https://doi.org/10.1007/s10584-017-1920-5

Intergovernmental Panel on Climate change (IPCC) (2007) Summary for Policymakers. In: Parry ML, Canziani OF, Palutikof JP, van der Linden PJ, Hanson CE (eds) Climate Change 2007: Impacts, Adaptation and Vulnerability. Contribution of Working Group II to the Fourth Assessment Report of the Intergovernmental Panel on Climate Change. Cambridge University Press, Cambridge, pp 722. https://doi.org/10.2134/jeq2008.0015br

Intergovernmental Panel on Climate change (IPCC) (2012) Managing the risks of extreme events and disasters to advance climate change adaptation. Cambridge University Press, Cambridge and New York, p 582 ISBN 978-1-107-02506-6

Jones PG, Thornton PK (2003) The potential impacts of climate change on maize production in Africa and Latin America in 2055. Glob Environ Chang 13:51-59. https://doi.org/10.1016/S0959-3780(02)00090-0

Jost C, Kyazze F, Naab J, Neelormi S, Kinyangi J, Zougmore R, Aggarwal P, Bhatta G, Chaudhury M, Tapio-Bistrom ML, Nelson S, Kristjanson $P$ (2016) Understanding gender dimensions of agriculture and climate change in smallholder farming communities. Clim Dev 8:133-144. https://doi.org/10.1080/17565529.2015.1050978

Kakota T, Nyariki D, Mkwambisi D, Kogi-Makau W (2015) Determinants of househols vulnerability to food insecurity: A case study of semi-arid districts in Malawi. J Int Dev 27:73-84. https:// doi.org/10.1002/jid

Kassie M, Ndiritu SW, Stage J (2014) What Determines Gender Inequality in Household Food Security in Kenya? Application of Exogenous Switching Treatment Regression. World Dev 56:153171. https://doi.org/10.1016/J.WORLDDEV.2013.10.025

Kassie M, Stage J, Teklewold H, Erenstein O (2015) Gendered food security in rural Malawi: why is women's food security status lower? Food Secur 7:1299-1320. https://doi.org/10.1007/s12571-015-0517-y

Keil A, Zeller M, Wida A, Sanim B, Birner R (2008) What determines farmers' resilience towards ENSO-related drought? An empirical assessment in Central Sulawesi, Indonesia. Clim Chang 86:291307. https://doi.org/10.1007/s10584-007-9326-4

Kinsey B, Burger K, Gunning JW (1998) Coping with drought in Zimbabwe: Survey evidence on responses of rural households to risk. World Dev 26:89-110. https://doi.org/10.1016/S0305750X(97)00124-1

Lawson D, Kasirye I (2013) How the extreme poor cope with crises: understanding the role of assets and consumption. J Int Dev 25: 1129-1143. https://doi.org/10.1002/jid.2968

Magrin GO, Marengo JA, Boulanger J-P, Buckeridge MS, Castellanos E, Poveda G, Scarano FR, Vicuña S, Alfaro E, Anthelme F, Barton J, Becker N, Bertrand A, Confalonieri U, de Souza AP, Demiguel C, Francou B, Garreaud R, Losada I, McField M, Nobre C, Lankao PR, Saldiva P, Samaniego JL, Travasso M, Viglizzo E, Villamizar A (2014) Central and South America. In: Barros VR, Field CB, Dokken DJ, Mastrandrea MD, Mach KJ, Bilir TE, Chatterjee M, Ebi KL, Estrada YO, Genova RC, Girma B, Kissel ES, Levy AN, MacCracken S, Mastrandrea PR, White LL (eds) Climate Change 2014: Impacts, Adaptation, and Vulnerability. Part B: Regional Aspects. Contribution of Working Group II to the Fifth Assessment Report of the Intergovernmental Panel on Climate Change. Cambridge University Press, Cambridge and New York, pp 1499-1566

Mallick D, Rafi M (2010) Are Female-Headed Households More Food Insecure? Evidence from Bangladesh. World Dev 38:593-605. https://doi.org/10.1016/J.WORLDDEV.2009.11.004
Mango N, Zamasiya B, Makate C, Nyikahadzoi K, Siziba S (2014) Factors influencing household food security among smallholder farmers in the Mudzi district of Zimbabwe. Dev South Afr 31: 625-640. https://doi.org/10.1080/0376835X.2014.911694

Maxwell S (1996) Food security: a post-modern perspective. Food Policy 21:155-170. https://doi.org/10.1016/0306-9192(95)00074-7

Maxwell D, Caldwell R, Langworthy M (2008) Measuring food insecurity: Can an indicator based on localized coping behaviors be used to compare across contexts? Food Policy 33:533-540. https://doi.org/ 10.1016/J.FOODPOL.2008.02.004

Milan A, Ruano S (2014) Rainfall variability, food insecurity and migration in Cabricán, Guatemala. Clim Dev 6:61-68. https://doi.org/10. 1080/17565529.2013.857589

Morris KS, Mendez VE, Olson MB (2013) 'Los meses flacos': seasonal food insecurity in a Salvadoran organic coffee cooperative. J Peasant Stud 40:423-446. https://doi.org/10.1080/03066150.2013.777708

Morton JF (2007) The impact of climate change on smallholder and subsistence agriculture. Proc Natl Acad Sci U S A 104:19680 19685. https://doi.org/10.1073/pnas.0701855104

Muche M, Endalew B, Koricho T (2014) Determinants of Household Food Security among Southwest Ethiopia Rural Households. Food Sci Technol 2:93-100. https://doi.org/10.13189/FST.2014.020701

Nyikahadzoi K, Siziba S, Mango N, Mapfumo P, Adekunhle A, Fatunbi O (2012) Creating food self reliance among the smallholder farmers of eastern Zimbabwe: exploring the tole of integrated agricultural research for development. Food Secur 4:647-656. https://doi.org/ 10.1007/s12571-012-0218-8

Patnaik U, Narayanan K (2015) Are traditional coping mechanisms effective in managing the risk against extreme events? Evidences from flood-prone region in rural India. Water Policy 17:724-741. https:// doi.org/10.2166/wp.2014.065

Porter JR, Semenov MA (2005) Crop responses to climatic variation. Philos Trans R Soc B-Biological Sci 360:2021-2035. https://doi. org/10.1098/rstb.2005.1752

Porter JR, Xie L, Challinor AJ, Cochrane K, Howden SM, Iqbal MM, Lobell DB, Travasso MI (2014) Food Security and Food Production Systems. Clim Chang 2014 Impacts, Adapt Vulnerability - Contrib Work Gr II to Fifth Assess Rep 485-533

Ramakrishna AG, Demeke A (2002) An Empirical Analysis of Food Insecurity in Ethiopia : The Case of North Wello. Africa Dev XXVII:127-143

Rozelle S, Taylor JE, DeBrauw A (1999) Migration, Remittances and Agricultural Productivity in China. AEA Pap Proc 89:287-291. https://doi.org/10.1086/250095

StataCorp (2011) Stata: Release 13. Statistical Software. StataCorp LP, College Station

Velazco J, Ballester R (2016) Food access and shocks in rural households: evidence from Bangladesh and Ethiopia. Social Indicators Research 129 (2):527-549. https://doi.org/10.1007/s11205-015-1118-z

Vermeulen SJ, Aggarwal PK, Ainslie A, Angelone C, Campbell BM, Challinor AJ, Hansen JW, JSI I, Jarvis A, Kristjanson P, Lau C, Nelson GC, Thornton PK, Wollenberg E (2012) Options for support to agriculture and food security under climate change. Environ Sci Policy 15:136-144. https://doi.org/10.1016/j.envsci.2011.09.003

World Food Programme (WFP) (2015) Análisis inicial del impacto de la sequía en la seguridad alimentaria en Guatemala, El Salvador y Honduras. Technical Brief. $4 \mathrm{p}$

World Food Programme (WFP) (2017) Food security and emigration: Why people flee and the impact on family members left behind in El Salvador, Guatemala and Honduras. Research report. Panama City, PA. 91

Publisher's note Springer Nature remains neutral with regard to jurisdictional claims in published maps and institutional affiliations. 